


\title{
ARTS AND CULTURE IN BUILDING AND SUSTAINING PEACE
}

\author{
Binod P. Bista, PhD
}

Secretary-General, Lumbini Research Center for Understanding and Peace

\begin{abstract}
Peace, harmony and development are essential conditions for any society, developed or developing, to progress. The 2011 World Development Report revealed that growing recognition of the link between social services, conflict and peace has helped in inclusion of social services' provision in peace agreements. A report from 'Policy Link' gives equitable development as the key to peace. Music plays a great role in building peace in conflict situations, so does religion, media, performance, theater. For achieving peaceful conditions there is a need to strike a balance between two extremes including inner and outer peace. Salzburg Global Seminar (2014) focused on using soft power, especially arts and culture, since cultural engagement helps transform perceptions. Case studies referred to in this write up provide sufficient evidence of the high usefulness of arts and culture in every phase of conflict. A detailed portfolio of case studies covering seven countries including Nepal of Asia describes the importance of 'narratives' and 'story telling', preservation of historical artifacts, photographs etc. for building peace mostly in post conflict stage. The researchers were of the view that the affected persons or beneficiaries needed to be involved right from the beginning of a peace project. British Council's publication named 'The Art of Peace' emphasizes on the importance of local actors' engagement as well as arts and cultural programs in linking culture, security and development. A project launched by the World Bank and the United Nations, entitled pathways to peace, offered guiding principles, namely, target institutional failure responsible for conflict, to be of inclusive nature, and form sustainable overtime character. Arts and Culture have a distinct place in resolving conflict thus it deserves adequate government support and a networking with other actors such as local municipalities, societies and groups.
\end{abstract}

Keywords: peace, conflict, arts culture, soft power, narratives, story telling, beneficiaries, inclusion 


\section{Understanding and achieving peace}

For any society to thrive, the existence of peaceful conditions is an absolute necessity. For, without peace and harmony, there is bound to be conflict which prevents progress and prosperity in a society. It is easier said than done since peace at a given point in time is based not only on the mindset of people but also technological progress that quickly changes the definition of needs. People and societies are dynamic, so is the definition of peace, the reason why no one has been able to achieve a common denominator of peace. The researchers and scholars, after having spent enormous amount of time in search of peace, chose the simplest definition as 'lack of violence or war' denoting peace. How far could it be from truth? Since peace is understood differently by different societies it signals that one needs to define the parameters for peace in every society. Imposed or imported peace does not last long as it directly threatens the culture and traditions besides disturbing the economic and social fabrics in a society.

Discussion on peace has consumed a lot of space on inequality in resources, lack of human rights including discrimination of all kinds, political power sharing and domination by the ruling class. Conflicts emerging from such issues are mostly resorted to good governance including transparency, accountability and rule of law. In other words, efforts are employed to find solutions to such conflicts through establishing new structures and mechanisms across a broad spectrum of activities. While such measures might help in the short and medium term they fail short of long term peace sustainability generally desired by all governments and people today. It is thus equally important to apply the right kind of interventions by the specialized agencies as well as research experts if certain positive change is expected.

Berghof paper on transition from violence to peace tries to combine two approaches: staged approach and systemic approach says the report. It states that the peace support agencies have to carefully examine the escalation or de-escalation of the conflict while intervening so as not to apply wrong instruments. It is advised to focus on one stage, depending on the specialization of the intervening organization, rather than attempting to cover up the entire range of possible interventions. The study report concludes that 'transition from violent social dynamics to constructive change' requires behavioral change as well as taming structural and cultural violence and the same can be achieved through distinct and complementary methodologies (Dudouet, 2006).

The 2011 World Development Report revealed that inability of local institutions to provide equitable access to justice and opportunities pushed societies to conflict and insecurity. Also the Sierra Leone case gave ample evidence that the armed groups formation there resulted from lack of access (inadequate) to education. The growing policy level recognition of the links between social services, conflict and peace has now led to the inclusion of social services related provisions in peace agreements. The case studies undertaken from Colombia to Rwanda and Iraq hit common chords highlighting the significant role of social services in shaping the daily life of individuals, households and communities (Rogan, 2014). (Smoker, 1996) 


\section{Importance of arts and culture to peace}

Arts played a major role in 'democratic transition' and giving voice to the marginalized. Additionally, creation of a central resource identifying successful projects, partnerships for short term and long term arts projects was given importance. Sharing of stories in online platform with clear message on commonalities of conflict, transcending time and space, and overall the power of media would be quite useful in conflict resolution (Emovwodo, 2017)

Programs and projects undertaken by Policy Link in the United States point to one direction - that of equitable development. The intersection of art, culture, and equitable development and policies to guarantee that intersection only will work for just and fair inclusion. Six methods have been advanced to bring about change on public policies that among others, includes economic development, expanded transportation access, enhanced youth development as well as healing from trauma and violence. These methods, starting from mapping of artistic and cultural communities, evaluating economic conditions, barriers to resources up to ensuring representative governance and staffing work well (Kalima Rose, 2017).

For bringing theory, policy and practice closer the recommendations adopted by the seminar focused on two aspects: Toolkit equipped for pre-conflict, during conflict and post conflict situation would be designed and applied for identifying the key players, stake holders in the conflict and their relationships - destructive and constructive, to conflict; case studies' compilation clearly revealing their influence on local, national and international policies. The document 'Peace, empathy, and conciliation through music: a collaboratory for future efforts', education needed to be revolutionized, marginalized voices inclusion as well as youth exchanges were called for (Dieckmann, 2017).

Lesley Pruitt conducted field research of non-governmental organizations in two places, Australia and Northern Ireland, to study utilization of music in peacebuilding and derived that music offered a mechanism for dialogue across differences for youth. Hindrances and restraints not withstanding the data suggested that music can be used to engage in peace dialogue (Pruitt, 2011).

"Music moves us and music moves with us", says the author. Thus, music has a great potential to affect peace and conflict in both directions, positive and negative. Music has tremendous appeal and influence to work for peace. Arts projects can be linked with other peacebuilding efforts for connecting to political, economic, and ongoing cultural projects. Though such a relationship may not provide the final answer to setting up lasting peace yet it can start an important process of social change, interconnection and healing (Adelman, 2011).

Less attention is paid to the relationship between religion and peace in spite of the instances that religion can be a powerful force for peacemaking. Religious leaders and religious people are found to be credible peace brokers having respect in their communities and ready access to cultural peace promoting reconciliation and forgiveness. From the data collected from 171 international peacemakers mostly Christian and white, there is certainly a good religious influence in peacekeeping thus more research needs to be carried for covering diverse race and rleigion in this area (Glazier, 2018). 
A paper published in the journal of International Peace Studies directs the attention of peace researchers and policy makers to an important need to strike a balance between "opposites" and "Extremes" including spiritual and material values (as suggested by Sorokin), between inner and outer aspects of peace such that inner component dealing with meditation or prayer and outer with opportunity and social justice. It was time to avoid either or formulations but include both/ and perspectives to set a fondation for peace in the Twenty First Century. In this action it is expected that the sharing of religious practices of the Eastern and Western spiritual traditions will play a critical role for peace (Smoker, 1996).

It is also believed that owing to various factors, particularly multiculturalism among others, there may be a need to focus on certain soft powers inherent in most societies such as arts, culture, media. One such global event conducted by The Edward T. Cone Foundation for Salzburg Global Seminar with support from several prominent foundations from the US and Asia and participated by artists, activists, policymakers, educators and cultural actors from 27 countries discussed several issues during April 6-10 (Seldl-Fox, 2014). The seminar focused its attention on transformative power of the arts series on peace-building, peacemaking, and conflict prevention through the arts. With the objective of the seminar aimed at fostering dialogue between representatives of cultural sector and others working for peace building and conflict prevention through arts, the participants first explored the role of arts in post conflict phase for reconciliation and society rebuilding. They (participants) further delved into 'soft power' strategies for peace in which arts can assisted in creating trust, advancing empathy, raising understanding and stimulating tolerance. For these stakeholders to connect there was a need for maximizing communication and the participants agreed that for effective conflict resolution cultural practices needed to be at the heart of conflict resolution as well (Seldl-Fox, 2014). The Salzburg Global Seminar rapporteur narrated participants' view on the importance of cultural engagement that helped transforming perceptions, especially how the 'other' was looked upon and thus providing a framework for re-humanization of societies that being the cornerstone of conflict transformation (Sridhar, 2014).

\section{Conflict resolution}

One of the participants stated clearly that while seeking conflict resolution an individual or a team should not prescribe formulas and let the affected persons do what they liked. Citing an example of the successful Truth and Reconciliation Commission of South Africa where a woman started singing in the middle of her testimony, he said that nobody should be forced into prescribed approaches to deal with their sufferings. Although cultural engagement projects helped to lessen the impact of violence still 'Romeo-Julietism' referred by James Thompson tended to reinforce divisions (real or assumed) that they were trying to change. Thompson also argued the deficient views that emerged from Maslow's hierarchy of needs where cultural aspirations were placed on top and Theodor Adorno's quote "to write poetry after Auschwitz is barbaric" failed to recognize the importance of art in conflict and post-conflict scenarios.

The outcome of the discussions revealed 
several areas where peace would be found. However, there may be a need to reorient the present thinking of 'minimalist approach' which is supposed to check physical violence to 'maximalist approach'.

That is supposed to also address causes of structural violence. Preserving cultural heritage and its role was cited as a powerful example in peace building. Though some monuments also depict oppression as well as freedom, victory the narratives associated with such monuments needed to be transformed for sustainability of peace. Concerning the interplay of identities, it was necessary to allow questioning and accepting with a view to creating space and embracing different identities. It was stated that there was a need to restore the link between artistic expression and civil society.

\section{Seven Asian countries case studies}

Culture is defined as the primary source that sets the boundaries between self and 'other', similar to Buddha's theory of 'dependent origination', lack of knowledge and understanding of this aspect in human life and unwillingness to accept the reality of differences between beings causes conflict in the first place. Ereshnee Naidu-Silverman, in seven Asian countries' case studies for identifying the role of arts and culture for peace and reconciliation, defined the useful role of art in all three phases of conflict - pre-in-post conflicts. In a 2015 publication of 'center for culture and development' she is of the view that art and culture can: provide early warning, support resistance, raise awareness and promote rebellion during the pre-conflict stage against repression. While during conflict it can relativize conflict, offers sympathy to those affected, acts as a coping mechanism, and provides hope. Art and culture at the post conflict phase can advance: healing \& therapy, dialogue and engagement, empathy, new identity formation, recognition of victims, crosscultural fluency, tolerance and trust among the parties concerned.

Pakistan's challenges are referred to as threats of extremism and religious fundamentalism, and elected government and a democratic system provides and enabling environment for securing peace and stability ultimately. For Sri Lanka's post conflict redress, stories are taken as an important tool for recognition and building empathy is taken as a key to reconciliation (Herstories (Baily, 2019) project). Nepal's case covered intensively in the case study credits New Picture Library Digital Photo Archive, Word Warriors, Siddhartha Art Foundation for their efforts in community engagement and empowerment as well as Karkhana, education organization, that worked with children enabling them to access some of the emotions masked by shock during the 2015 earthquake. Nevertheless, artistic initiatives receive little or no support from the national government thus the success for Nepal is placed with the ability to network and collaboration among the artists, education specialists and the social activists. In Afghanistan, lacking a truth-telling mechanism, the Afghanistan Human Rights and Democracy Organization (AHRDO) utilized playback theater for enacting spontaneous stories by actors and audience. Art is taken as a less controversial and accessible tool in Afghanistan. In Myanmar, too, facilitating dialogue through arts to build empathy and trust among ethnically divided communities is relatively successful as people engage honestly and 
take risks. Also as in several instances art is a non-threatening tool to address social issues. In Bangladesh, by recognizing suffering and heroism of Bangladeshis an attempt is made to impress on the futility of violent conflict through

inter-generational transfer of memory. In Indonesia art is accepted to be a medium for building relationships and creating dialogue besides artistic production and thus promotes tolerance and religious freedom. While partnering with local organizations provided access to diverse beneficiaries, the use of popular art and education methods achieved positive results in short timeframe and required less resources.

By way of sharing lessons the project offered the recommendations for successful use of art and culture in peace and reconciliation as: identify beneficiaries' needs and involve them at the design phase itself, alternate art methods such as visual art or music may be more suitable as per context and prior consultation with beneficiaries creates ownership of a project; 'Survivor fatigue' owing to the influx of national and international organizations may turn the project into a failure, and using local tools and traditions is a pathway to success. For societies emerging from conflict a range of social, cultural and political concerns need to be addressed including justice for victims, narratives about the past, space for rebuilding relationships, healing and forgiveness and so on. While these concerns need to be addressed at all levels, art and culture bear the potential to address some of them (Naidu-Silverman, 2015).

A publication of the British Council named "The art of Peace" authored by Alison Baily focuses on the value of culture in post-conflict recovery (Baily, 2019). The report, as a joint collaboration of the British Council and the University of the West of Scotland, highlights the importance of local actors' engagement in projects and the role of cultural identity in redressing damage caused by conflict. The project highlights emerging evidence of arts and cultural programs' part in linking culture, security and development. Therapy, reconciliation and civil society strengthening result from arts and cultural programs and Rwanda is taken as a notable example. A number of programs were undertaken in Colombia, Syria and Rwanda where peace and security were accepted as subsidiary benefits by improving social cohesion and resilience. Due to small scale of many programs, the author vis a vis the Council agrees that it produced a mixed bag of result indicating the need for more research work on the role of arts and culture to peace. In this regard further research is warranted in the areas of: security and stability, focus on tangible and realistic goals, design in a conflict-sensitive manner, opportunities to try innovative and creative approaches (Baily, 2019).

The booklet entitled "pathways for peace: Inclusive Approaches to Preventing Violent Conflict" under the integrated core team led by Alexandre Marc (WB) and co-led by Jago Salmon (UN/WB partnership on conflict and fragility, the United Nations) with editing done by Susan Sachs contains 65 pages in all. This report is based upon the available knowledge on the nexus between development and conflict. It has come out as a result of a combination of literature review, a series of country case studies and a number of new thematic papers. In the process the core team conducted consultations within the World Bank and the United Nations as well as outside including the donors. 
It comes out with guidelines for state, regional and global level foundations for prevention of conflict and sustenance of peace. The guiding principles point to three areas: actively and directly target institutional failure fueling the risk of conflict; must be inclusive; and must be sustained overtime. Preventions in situations of emerging risks need to address sources of grievances and contribute to perceptions of exclusion. In such situations diplomacy can play a constructive role. The focus needs to be provided to ensure both accountability and core functioning of the security sector. Besides the guidelines also touch upon integrated planning across political, security, humanitarian, and development areas of engagement for preventing recurrence of conflict (World Bank Group and the United Nations, 2017).

\section{Conclusion}

In conclusion it can be said with a greater degree of confidence that Arts and Culture have a distinct place in resolving conflict, mostly in post conflict situations, and can lead to a long term peace prospect given the right networking with other actors such as government, local municipalities, local groups and societies. Care must be taken to see that the affected persons or expected beneficiaries are involved from the design phase itself to implementation and sustenance for success of any project.

\section{Bibliography}

Adelman, E. (2011, March 28). The Processes of Music and Peacebuilding. Retrieved 11 17, 2020, from Beyond Intractability.

Baily, A. (2019). The Art of Peace. Brirish Council. UK: The British Council.

Dieckmann, J. W. (Director). (2017, September 2122). Peace, Empathy and Conciliation through Music: A Collaboratory. (t. w. The ARC Center of Excellence for the History of Emotions, Performer) The University of Melbourne, Center for Theology and Ministry, Parkville, VIC, Australia.

Dudouet, V. (2006). Transition from Violence to Peace. Berlin: Berghof Research Center for Constructive Conflct Management.

Emovwodo, S. O. (2017). Media Roles in Harnessing Art for Peace Building in Improving Socio-Cultural Community Life. (p. 09). RG Academic Publishers \& Reviewers.

Glazier, R. A. $(2018,11)$. How Religion Influences Peacemaking. Peace and Conflict Studies, 25(2/article 3), p. 26.

Kalima Rose, M. H. (2017). Creating Change through Arts, Culture, and Equitable Development: A Policy and Practice Primer. PolicyLink. NY, CA, WA: PolicyLink.

Lajunen, D. W. (2017). Music, Inner Peace and Social Harmony. Dissertation.

Mozara, Z. (2015, 12 10-13th). The Role of Music in the Conflict--Tool of Reconciliation or a Deadly Weapon. The Annual Conference on Cultural Diplomacy, 15. Berlin: NA.

Naidu-Silverman, E. (2015, September). The Contribution of Art and Culture in Peace and Reconciliation Processes in Asia. 57. Copenhagen, Denmark: Centre for Culture and Development.

Pruitt, L. (2011, Spring/Summer). Creating a Musical Dialogue for Peace. International Journal of Peace Studies, 16(Number 1), 81-103.

Rogan, E. M. (2014, February 05). Bringing Peace Closer to the People: The Role of Social Services in Peacebuilding. Journal of Peacebuilding \& Development, 8(3), 1-6.

Seldl-Fox, S. (2014). Program Director for culture and arts. Conflict Transformation through Culture (pp. 05-06). Salzburg: Salzburg Global Seminar.

Smoker, L. G. (1996, January). Spirituality, Religion, Culture, and Peace: Exploring The Foundations for Inner-Outer Peace in the Tewnty-First Century. International Journal of Peace Studies, 1(1), 57-113.

Sridhar, S. (2014). Rapporteur's report. Conflcit Transformation and Culture: Peace Building through the Arts (pp. 07-08). Salzburg: Salzburg Global Seminar.

World Bank Group and the United Nations. (2017). Main Messages and Emerging Policy Directions. Pathways for Peace, 65. Washington, DC: World Bank Publications. 